\title{
P178: The IPC program in West-Africa: how do you make it feasible and useful?
}

\author{
B Ndoye \\ From 2nd International Conference on Prevention and Infection Control (ICPIC 2013) \\ Geneva, Switzerland. 25-28 June 2013
}

\section{Introduction}

Africa generally, West-Africa in particular, is characterized by a remarkable lack of structured national IPC programs. There are numerous challenges to face, but there are also existing opportunities, which can enable to improve the current situation by using a rational and adapted approach.

\section{Objectives}

The objective is to present the best way to implement IPC programs in Francophone West-Africa.

\section{Methods}

The author propose a concrete way to implement increasingly a comprehensive national IPC program, based on main challenges (specially the lack of human resources), and the numerous opportunities as the many tools and guidelines currently proposed by WHO to face IPC, NGO's supporting countries to strengthen the health system, and specially Senegalese experience.

\section{Results}

Recommendations are based above all on two strategic issues:

- Human resources development

- Implementation of a national program, primarily based on basic processes (Standard Precautions).

\section{Conclusion}

Starting national programs in West-Africa is feasible, useful and necessary, with currently available resources. That implies a political willingness of the countries and the support of development partners. These programs should firstly be based on basic processes of IPC, which are cross-cutting, involve all categories of healthcare

Afrhyquasec, Dakar, Senegal workers, and don't need specialized knowledge and skill. Starting from this entry point, the programs will be strengthened and adapted to local realities, in order to become increasingly really national programs for Patient Safety, with the human resources development.

All this will be achieved through a Senegalese project which aims at implementation of national patient safety programs in francophone West-Africa, starting with IPC activities.

\section{Disclosure of interest}

None declared.

Published: 20 June 2013

\section{doi:10.1186/2047-2994-2-S1-P178}

Cite this article as: Ndoye: P178: The IPC program in West-Africa: how do you make it feasible and useful? Antimicrobial Resistance and Infection Control 2013 2(Suppl 1):P178.
Submit your next manuscript to BioMed Central and take full advantage of:

- Convenient online submission

- Thorough peer review

- No space constraints or color figure charges

- Immediate publication on acceptance

- Inclusion in PubMed, CAS, Scopus and Google Scholar

- Research which is freely available for redistribution

Africulac

(c) 2013 Ndoye; licensee BioMed Central Ltd. This is an Open Access article distributed under the terms of the Creative Commons 